\title{
RELATÓRIO ANUAL, 1993
}

No seu $27^{\circ}$ ano de publicações, sem interrupçōes, a Revista da Escola de Enfermagem da USP (Rev.Esc.Enf.USP), vem mantendo seus volumes com regularidade, periodicidade e seqüência.

Embora com atraso na edição, principalmente, deste volume, pela dificuldade de obtenção de recursos financeiros, a Rev.Esc.Enf.USP temse dedicado a publicar artigos originais de pesquisa e de atualização objetivando atingir leitores tanto voltados às atividades de aperfeiçoamento no meio acadêmico quanto aos profissionais prestadores de serviços. Os temas dos artigos foram variados e neste sentido publicaram-se artigos referentes às áreas médicas, cirúrgicas, psiquiátrica, oncológicas, preventiva,entre outras.

Os trabalhos enviados foram submetidos à avaliação dos membros que compõem o Conselho Editorial e dos avaliadores que compóem o banco de dados constituído de docentes, pesquisadores e enfermeiros da área assistencial ("membros assessores"). Cada manuscrito enviado pelo Autor ao Editor foi verificado, "a priori", se enquadra-se na política editorial da Revista. Posteriormente foi encaminhado aos relatores que emitiram pareceres sobre a publicação do artigo.

Os membros assessores deste volume prestaram valiosa coloaboração emitindo pareceres cuidadosos e judiciosos que contribuíram para a manutenção da qualidade dos trabalhos publicados neste volume.

Foram submetidos à apreciação em 1993 36.trabalhos, destes 21 são artigos originais de pesquisa; 12 trabalhos de atualização; 01 nota prévia, 02 resumos de teses e dissertações.

$\mathrm{Na}$ edição do volume $27 \mathrm{um}$ fascículo foi financiado pelo SIBI (Comissão de Credenciamento da Revista) e os dois restantes foram patrocinados pela EE, que garantiu ainda, recursos para distribuição e postagens.

A Rev.Esc.Enf.USP, em 1993, editou (70\%) artigos de autores residentes no Estado de São Paulo e (30\%) de outros Estados.

Contou-se na edição deste volume com a contribuição de pessoas que executam tarefas específicas. Neste sentido, como vem acontecendo há muitos anos, D. Maria Rosa Souza Pinheiro, ex-diretora da EE-USP, colaborou emitindo pareceres e fazendo revisāo da lingua portuguesa dos artigos para publicação. A versão de resumos dos artigos, para o idioma inglês foi executada pelas docentes Dulce Maria Rosa Gualda e Estela Regina Bianchi Ferraz que se empenharam em executar esta tarefa de forma cuidadosa e eficiente. 
O elevado custo para a produção de um fascículo de Revista levounos a utilizar formas alternativas de elaboração dos dois últimos números deste Volume, recorrendo aos recursos de informática na edição de textos e aos serviços de grafia da EEUSP na reprodução da totalidade da tiragem.

Enfim, para a concretização da publicação do volume 27 , foi necessária a colaboraçāo de uma infra-estrutura eficientíssima composta pela equipe coordenada pela Bibliotecária Alaide Moura de Oliveira, Diretora do Serviço de Biblioteca e Documentação da EEUSP. A parte da Secretaria, revisão de provas, distribuição, anuidade, cartas, estiveram a cargo da competente funcionária Ana Elisa Vieira. Editorial.

A todos os colaboradores os sinceros agradecimentos do Conselho

\author{
Hideko Takeuchi Forcella \\ Presidente \\ Comissão de Biblioteca e Publicações
}

